\title{
Natal Dispersal Distance of Bald and Golden Eagles Originating in the Coterminous United States as Inferred from Band Encounters
}

\author{
Author(s): Brian A. MillsapAlan R. HarmataDale W. StahleckerDavid G. \\ Mikesic
}

Source: Journal of Raptor Research, 48(1):13-23.

Published By: The Raptor Research Foundation

https://doi.org/10.3356/JRR-13-00005.1

URL: http://www.bioone.org/doi/full/10.3356/JRR-13-00005.1

BioOne (www.bioone.org) is a nonprofit, online aggregation of core research in the biological, ecological, and environmental sciences. BioOne provides a sustainable online platform for over 170 journals and books published by nonprofit societies, associations, museums, institutions, and presses.

Your use of this PDF, the BioOne Web site, and all posted and associated content indicates your acceptance of BioOne's Terms of Use, available at www.bioone.org/ page/terms_of_use.

Usage of BioOne content is strictly limited to personal, educational, and noncommercial use. Commercial inquiries or rights and permissions requests should be directed to the individual publisher as copyright holder. 


\title{
NATAL DISPERSAL DISTANCE OF BALD AND GOLDEN EAGLES ORIGINATING IN THE COTERMINOUS UNITED STATES AS INFERRED FROM BAND ENCOUNTERS
}

\author{
Brian A. MiLlsap 1 \\ Division of Migratory Bird Management, U.S. Fish and Wildlife Service, 2105 Osuna NE, Albuquerque, \\ NM 87113 U.S.A.
}

Alan R. Harmata

Ecology Department, Montana State University, Bozeman, MT 59717 U.S.A.

DALE W. STAHLECKER

Eagle Environmental, Incorporated, 30 Fonda Road, Santa Fe, NM 87508 U.S.A.

DAVID G. MiKesiC

Navajo Nation Zoo, P.O. Box 1329, Window Rock, AZ 86515 U.S.A.

\begin{abstract}
We reviewed band encounter data for Bald Eagles (Haliaeetus leucocephalus) and Golden Eagles (Aquila chrysaetos) to estimate natal dispersal distances for both species in the coterminous United States (U.S.). We filtered band recovery data to focus on individuals banded as nestlings, encountered at ages old enough to be breeding, and encountered at times of the year when they may be at or near breeding or prospective breeding sites. Our final data set included 96 Golden Eagles and 878 Bald Eagles. Distances between banding and subsequent encounter sites for both species were lognormally distributed. We employed both traditional and Bayesian methods of analysis, and obtained similar results from both approaches. Bayesian analysis of banding data suggest a median natal dispersal distance of 69.2 (95\% highest density interval $[\mathrm{HDI}]=63.5-73.1) \mathrm{km}$ for Bald Eagles and $46.4(\mathrm{HDI}=36.0-55.2) \mathrm{km}$ for Golden Eagles. Median natal dispersal distance for female Bald Eagles 78.3 was (HDI $=35.4-128.6) \mathrm{km}$ greater than for males; we lacked sufficient data to analyze natal dispersal distance by sex for Golden Eagles. Median Bald Eagle natal dispersal distance did not differ among eight regional populations, but there was evidence of a trend toward increasing natal dispersal distance from east to west across the coterminous U.S. Our findings are compatible with natal dispersal data in the literature for both species. The U.S. Fish and Wildlife Service uses estimated natal dispersal distance of Bald and Golden eagles to set one of the geographic scales at which the effects of permits that authorize the "take" (removal from the wild) of eagles is evaluated. Our analyses suggest that choice of a natal dispersal value in the range of the $50^{\text {th }}-90^{\text {th }}$ quantile of the distribution as an effect-area for modeling or effect-assessment for both species of eagle is reasonable. For Golden Eagles, this range is $46-175 \mathrm{~km}$, and for Bald Eagles $69-346 \mathrm{~km}$.
\end{abstract}

KeY Words: Bald Eagle, Haliaeetus leucocephalus; Golden Eagle; Aquila chrysaetos; bird banding; dispersal; natal dispersal; sex-biased dispersal.

DISTANCIA DE DISPERSIÓN NATAL DE HALIAEETUS LEUCOCEPHALUS Y AQUILA CHRYSAETOS ORIGINADA EN ESTADOS UNIDOS CONTIGUO INFERIDA A PARTIR DE ENCUENTROS DE ANILLOS

RESUMEN.-Examinamos datos de encuentros de anillos de Haliaeetus leucocephalus y Aquila chrysaetos para estimar las distancias de dispersión natal para ambas especies en Estados Unidos contiguo (EEUU). Filtramos datos de recuperación de anillos para enfocarnos en individuos anillados cuando eran pichones, encontrados a edades suficientes como para estar reproduciéndose y encontrados en épocas del año cuando pueden estar en o cerca de sitios de reproducción o de sitios de prospección de reproducción. Nuestro grupo de datos final incluyó 96 individuos de A. chrysaetos y 878 individuos de H. leucocephalus. Las

${ }^{1}$ Email address: brian_a_millsap@fws.gov 
distancias entre los sitios de anillado y los de encuentro subsecuente para ambas especies presentaron una distribución log-normal. Utilizamos tanto métodos de análisis tradicionales como bayesianos y obtuvimos resultados similares con ambos métodos. El análisis bayesiano de los datos de anillado sugiere una distancia de dispersión natal mediana de 69.2 (95\% de intervalo de densidad mayor [IDM] = 63.5-73.1) $\mathrm{km}$ para $H$. leucocephalus y 46.4 (IDM $=36.0-55.2) \mathrm{km}$ para A. chrysaetos. La distancia de dispersión natal mediana para hembras de $H$. leucocephalus fue 78.3 (IDM = 35.4-128.6) $\mathrm{km}$ más grande que para los machos; faltaron datos suficientes para analizar la dispersión natal por sexos para A. chrysaetos. La distancia de dispersión natal mediana de $H$. leucocephalus no difirió entre ocho poblaciones regionales, pero se encontró evidencia de una tendencia hacia un incremento de la distancia de dispersión natal de este a oeste en EEUU contiguo. Nuestros resultados son compatibles con los datos de dispersión natal en la literatura para ambas especies. El Servicio de Pesca y Vida Silvestre de EEUU usa la distancia de dispersión natal estimada para $H$. leucocephalus para determinar una de las escalas geográficas en la cual se evalúan los efectos de los permisos que autorizan la colecta (remoción del estado silvestre). Nuestros análisis sugieren que la elección del valor de dispersión natal en el rango del $50^{\circ}-90^{\circ}$ cuartil de la distribución como un área de modelado o de evaluación para ambas especies de águila es razonable. Para A. chrysaetos, este rango es de 46-175 km y para H. leucocephalus es de 69-346 km.

[Traducción del equipo editorial]

Natal dispersal in birds is defined as the movement between hatching location and first breeding or potential breeding location (Greenwood and Harvey 1982). Natal dispersal has important biological and conservation consequences, yet it is poorly understood in most raptors, at least in part due to difficulties in tracking such long-term and potentially wide-ranging movements (Penteriani and Delgado 2009). As noted by Whitfield et al. (2009), most movements affecting gene flow and demography in raptors are a result of natal dispersal. One important conservation application of natal dispersal distance is to define the geographic scope of potential population effects of a management action (González et al. 2006). Here, we designate this as the "effect area," and we consider it the larger geographic area affected by the numeric depletion of a local eagle population through, for example, overharvest. The effect area is the area over which recruits could be generated to replenish or "rescue" the depleted local population. Because Bald ( $\mathrm{Ha}$ liaeetus leucocephalus) and Golden (Aquila chrysaetos) eagles are density-dependent breeders limited by territoriality and a finite number of nest sites (Hunt 1998, Buehler 2000, Kochert et al. 2002), the size of the effect area is likely strongly influenced by the dispersal distance of offspring (Penteriani and Delgado 2009, Penteriani et al. 2011).

U.S. Fish and Wildlife Service (2009a) used estimated natal dispersal distance of Bald and Golden eagles to establish as policy the effect area for biological assessments to determine whether or not to issue permits for "take" (removal from the wild) of eagles. Examples of take that can be permitted under the existing regulations include removal of eagles by Native Americans for cultural and religious purposes, and incidental mortality and disturbance associated with otherwise lawful activities (e.g., wind development projects, electric utility distribution). The U.S. Fish and Wildlife Service (2009a) performed a cursory analysis of band encounter data for both species of eagle to estimate natal dispersal distance for use in such assessments; that analysis did not fully consider all banding data available for either species or explicitly consider variance in natal dispersal distance, or the implications of that variation for either species. Moreover, the Golden Eagle dataset used included several longdistance records for Alaskan Golden Eagles that probably represented migration rather than natal dispersal.

The purpose of this report is to revisit and update the natal dispersal analysis reported by the U.S. Fish and Wildlife Service (2009a). Our objective was to further evaluate all available and appropriate banding data, to focus on records likely to represent natal dispersal, and to evaluate implications of variance in estimates of natal dispersal when used for conservation purposes. We chose to focus on eagles originating from natal sites in the lower 48 states of the United States (coterminous U.S.) because: (1) banding data were available for most parts of each species' breeding range at this geographic scale; and (2) restricting our sample to temperate latitudes simplified accommodating changes in breeding chronology with latitude. Band encounter data provide a large and easily accessible data set for the estimation of natal dispersal distances, although not without limitations. Without question, the best data set for such an analysis would consist of information from radio-tagged eagles followed from fledging 
through first breeding. Such data do not presently exist for either species of eagle in sufficient samples for statistical analysis, though they may in the future. Until that time, band encounters provide the best data with which to estimate natal dispersal distances for eagles.

\section{Methods}

We began with a sample of 670 Golden Eagles and 4276 Bald Eagles banded as nestlings that were later encountered and reported (data provided by U.S. Geological Survey [USGS] Bird Banding Laboratory $[\mathrm{BBL}]$, Patuxent, Maryland, U.S.A.). Banding data have three main limitations with respect to analysis of dispersal distances. First, breeding status of encountered eagles is seldom known with certainty. Second, encounters obtained through resighting bands can be biased if those resightings are the result of searches constrained by study area boundaries (Baker et al. 1995, Koenig et al. 1996). Finally, the exact date and location of some encounters is not precisely known. We applied several filters to the data to minimize these biases and focused on records of eagles banded in the coterminous U.S. that were subsequently encountered at or near their breeding site or prospective breeding area.

First, we removed all eagles encountered (recaptured or found dead or injured) before $4.75 \mathrm{yr}$ postbanding (estimated age at first breeding) or of unknown age at the time of encounter ( $n=479$ Golden Eagles, 2547 Bald Eagles). We considered age at first breeding of $4.75 \mathrm{yr}$ conservative for Golden Eagles because Steenhof et al. (1983) found $<3 \%$ of breeding adults in Idaho were in subadult plumage and adult plumage is usually attained in no less than 4 yr (Jolie 1947, Brown and Amadon 1968, Wheeler and Clark 1995, Bloom and Clark 2001). Further, Steenhof et al. (1984) found no Golden Eagle banded as a nestling returning to its natal area $(n=6)$ earlier than 4 yr. Similarly, few Bald Eagles have been recorded breeding in subadult plumage, and adult plumage in this species is attained at no less than 4 yr (Brown and Amadon 1968, Buehler 2000). We checked whether $4.75 \mathrm{yr}$ was a reasonable age cutoff for natal dispersal estimation using a linear model to test for an effect of increasing age on natal dispersal distance.

Second, we deleted any records with codes indicating a band or band and bone only were recovered because of uncertainty of true age or location at removal from the population ( $n=73$ Golden Eagles, 9 Bald Eagles). We deleted records of eagles known to have been held at rehabilitation facilities, reported from the U.S. Eagle Repository, or without encounter coordinates for similar reasons $(n=0$ Golden Eagles, 6 Bald Eagles). Third, we removed records involving eagles banded at locales outside the coterminous U.S. $(n=20$ Golden Eagles and $n=138$ Bald Eagles banded in Alaska, Canada, or Mexico), eagles banded outside the current natural breeding range of the species based on range maps in Buehler (2000) and Kochert et al. (2002; $n=1$ Golden Eagle banded in Georgia), and eagles with reencounter locations specific only to the state or country level $(n=1$ Golden Eagle and $n=5$ Bald Eagles). Fourth, we identified records that were the result of resightings by the bander or banding agency ( $n=11$ Golden Eagles and $n=92$ Bald Eagles), and used a Bayesian fixed-effect analysis of variance (ANOVA) to estimate the difference between posterior means of that sample and the sample of bands reported by members of the public. Our goal with this analysis was to determine if bander-reported records imparted a study-area bias and should be omitted from the analysis.

Finally, we subdivided the coterminous U.S. into four latitudinal zones to account for latitudinal variation in Bald Eagle breeding chronology (Buehler 2000). We set acceptable breeding dates for records in each latitudinal zone to maximize the likelihood our sample included only Bald Eagles at or near breeding or potential breeding locations. Breeding dates of Bald Eagles from natal areas $\leq 32.5^{\circ} \mathrm{N}$ latitude spanned 1 November through 31 March; from natal areas between $32.5^{\circ}$ and $\leq 35.0^{\circ} \mathrm{N}$ latitude spanned 1 December through 30 April; from natal areas between $35.0^{\circ}$ and $\leq 40^{\circ} \mathrm{N}$ latitude spanned 1 January through 31 May; and from natal areas in the coterminous U.S. $>40^{\circ} \mathrm{N}$ latitude spanned 1 February through 31 June $(n=698$ Bald Eagles removed). Although these zones are somewhat subjective, we believe they adequately account for latitudinal variation in Bald Eagle breeding chronology, yet maintain adequate samples sizes for analysis in each zone. We did not filter Golden Eagle records for time of year because in the U.S. west of the 100th meridian Golden Eagles are believed to reside year-round on their breeding territories (Kochert et al. 2002). There is some evidence from radio-tagged eagles that this may not always be the case (R. Murphy and D. Stahlecker unpubl. data; A. Harmata unpubl. data), so as a check on this assumption we filtered Golden Eagle records to exclude encounters outside of the period February through 
June (the breeding season) and compared natal dispersal distance estimates for the two samples using a Bayesian fixed-effect ANOVA.

In addition to our overall analysis of natal dispersal distances, we compared natal dispersal distances by sex and region for the Bald Eagle. Only 13 Golden Eagle records were of known-sex individuals, and the overall sample for this species was too sparse for meaningful assessments of geographic variation. We evaluated geographic variation in natal dispersal in Bald Eagles by comparing natal dispersal distances for eight regional geographic populations that had $>15$ records each using a random-effects ANOVA in a Bayesian framework (Kery 2010). The number of known-sex records was insufficient for separate analyses of males and females, so we pooled all records under the assumption that sex ratios were similar among populations. This seemed reasonable because the sex ratio was approximately equal in the known-sex sample for Bald Eagles (67 males and 71 females). The regional populations we evaluated were: (1) Maine, (2) Chesapeake Bay (Maryland, Delaware, and Virginia), (3) southeast (South Carolina, Georgia, and Florida), (4) Great Lakes (Michigan, Minnesota, and Wisconsin), (5) Midwest (Indiana, Illinois, Missouri, and Tennessee), (6) Greater Yellowstone Ecosystem (Idaho, Montana, and Idaho), (7) Southwest (Arizona); and (8) Pacific coast (Washington, Oregon, and California). We also compared our results with a smaller sample of confirmed natal dispersal distances from studies in the Greater Yellowstone Ecosystem in Montana and Wyoming (Harmata et al. 1999) and Florida (Millsap et al. 2004). In the case of the Florida study, we report previously unpublished natal dispersal data for four individuals that were banded as part of that study and subsequently confirmed to be breeding. For Golden Eagles, we compared our estimates for natal dispersal with the few records that have been reported in the literature.

Banding (natal nest) and encounter locations were provided by BBL in coordinates of the southeast corner of the 10-min latitude-longitude block. We calculated distances between coordinates of banding and encounter 10-min blocks using the "rdist.earth" function in the "fields" package (Furrer et al. 2009) in $\mathrm{R}$ ( $\mathrm{R}$ Development Core Team 2008). We compared empirical distributions of distances between natal and encounter locations for each of the four band encounter datasets (Golden Eagles, all Bald Eagles, female Bald Eagles, male Bald Eagles) to several plausible theoretical distri- butions (normal, lognormal, gamma) using the "fitdistrplus" package (Delignette-Muller et al. 2012) in R. We identified the best-fitting theoretical distribution in each case based on the smallest AIC score and Kolmogorov-Smirnov (KS) goodness-of-fit test result. We estimated parameters of the assumed underlying distribution given the data three ways: (1) directly from the sample of band encounter distances; (2) using the maximum likelihood procedure in "fitdistrplus"; and (3) using Bayesian methods. For the latter, and for all other Bayesian analyses, we used uninformative uniform priors and the Markov chain Monte Carlo (MCMC) method implemented in program WinBUGS (Lunn et al. 2000) to estimate posterior distributions of parameters. For the lognormal distribution, the back-transformed geometric mean (the median) is $e^{\mu}$, where $\mu$ is the estimated mean of the log-transformed values, and the arithmetic mean is $e^{\mu+1 / 2 \sigma^{2}}$, where $\sigma$ is the estimated standard deviation of the log-transformed values (Daly 2000).

Our Bayesian fixed- or random-effects one-way ANOVAs and normal linear model follow the approach recommended by Kery (2010). In the latter analysis, we were interested in whether the slope $(\beta)$ of the line fitted to natal dispersal distance with age was different from zero. In each Bayesian analysis, we ran three chains for 10000 iterations and used the first 100 iterations for a burn-in period and made inferences using the final 9900 iterations for each of the chains. Therefore, our final summary statistics are based on a total of 29700 iterations. We inspected history plots and $\hat{R}$ values to ensure models converged; all model results reported here had $\hat{R}$ values $\leq 1.03$, which indicates convergence (Gelman and Hill 2007). For posterior distributions or values derived from posterior distributions, we used the $95 \%$ highest density interval (HDI) to identify values of the posterior distribution of parameters considered credible, following Kruschke (2011). This is the Bayesian equivalent of the $95 \%$ confidence interval, but has substantial advantages when the parameter estimates are in the form of posterior distributions (Kruschke 2011). We considered posterior parameters to be credibly different if HDIs of the differences between posterior means excluded zero (Kruschke 2011).

\section{RESULTS}

After applying filters, our sample size was 96 Golden Eagles and 878 Bald Eagles (Fig. 1, 2). For Bald 


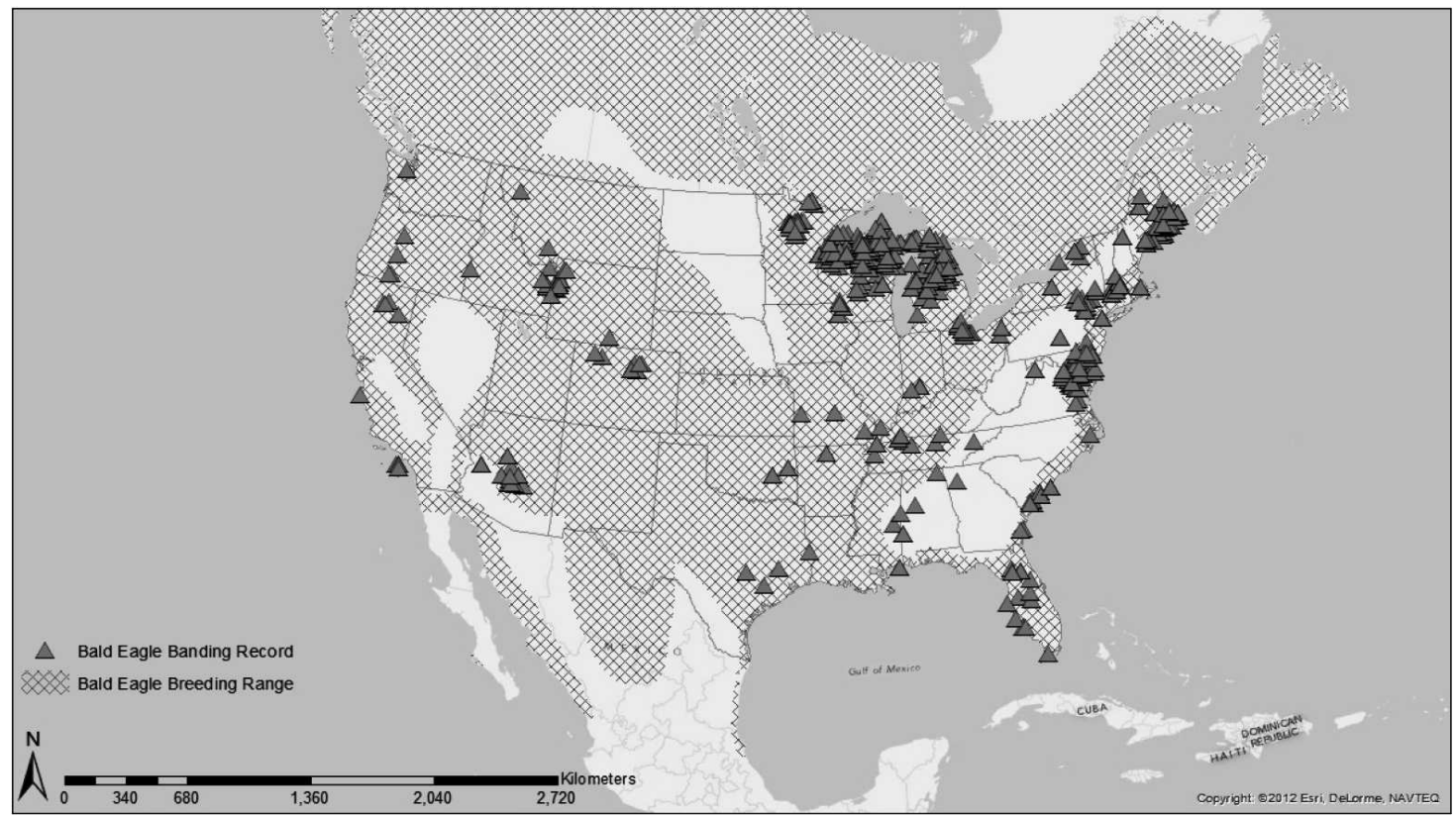

Figure 1. Breeding range (from Ridgely et al. 2007) and natal banding sites of Bald Eagles subsequently encountered and included in natal dispersal analysis.

Eagles, 137 records were of individuals of known sex, 67 males and 70 females. Dispersal distances in all four datasets (Golden Eagle, Bald Eagle, female Bald Eagle, and male Bald Eagle) best fit the assumption they were from lognormal distributions, although this assumption failed the goodness-of-fit test for the pooled Bald Eagle dataset (Table 1). Regardless, given that the lognormal was the best fit judging from AIC values in each case, we proceeded with our analyses based on the assumption the samples were from such a distribution.

The HDI for the difference in the posterior mean log-transformed natal dispersal estimates from Golden Eagle datasets with all records and a subset from the breeding season included zero (posterior mean difference $=-0.28$, HDI $=-0.69-0.13 \mathrm{log}$ $\mathrm{km})$. Because zero was a credible value for the difference between the two distributions, we concluded they were similar and therefore used the full Golden Eagle dataset in subsequent analyses. Similarly, we found no evidence of an effect of age past $4.75 \mathrm{yr}$ on natal dispersal distance in either Bald or Golden Eagles (Bald Eagle: $\beta=0.00174$, HDI $=$ -0.012-0.016; Golden Eagle: $\beta=-0.022$, HDI $=$ $-0.05782-0.016)$; we concluded $4.75 \mathrm{yr}$ was an appropriate age cutoff for our analyses. Finally, the HDIs for the difference in the log-transformed posterior mean natal dispersal distances for banderreported eagles and those reported by the public included zero for both Bald and Golden eagles (Bald Eagle mean posterior difference $=-0.19$, HDI $=-0.46-0.08$; Golden Eagle mean posterior difference $=0.41$, HDI $=-0.18-1.07)$. We concluded there was not a study area effect in eagle resighting data, thus we retained resightings obtained by banders in our analyses.

Median and arithmetic mean natal dispersal distance estimates were greater for Bald Eagles than Golden Eagles, and the means were greater than the median (Table 2), which is typical for positively skewed distributions (Fig. 3). For Bald Eagles, median natal dispersal distance was greater for females than males (Fig. 4). The Bayesian analysis indicated that female Bald Eagle median natal dispersal distance was 78.3 (HDI $=35.4-128.6) \mathrm{km}$ longer than that of males (Fig. 4).

All regional Bald Eagle posterior median natal dispersal distance HDIs included the grand median; thus, we found no evidence for marked differences in natal dispersal distance among regions. However, there was a trend toward greater natal dispersal distances from east to west across the United States 


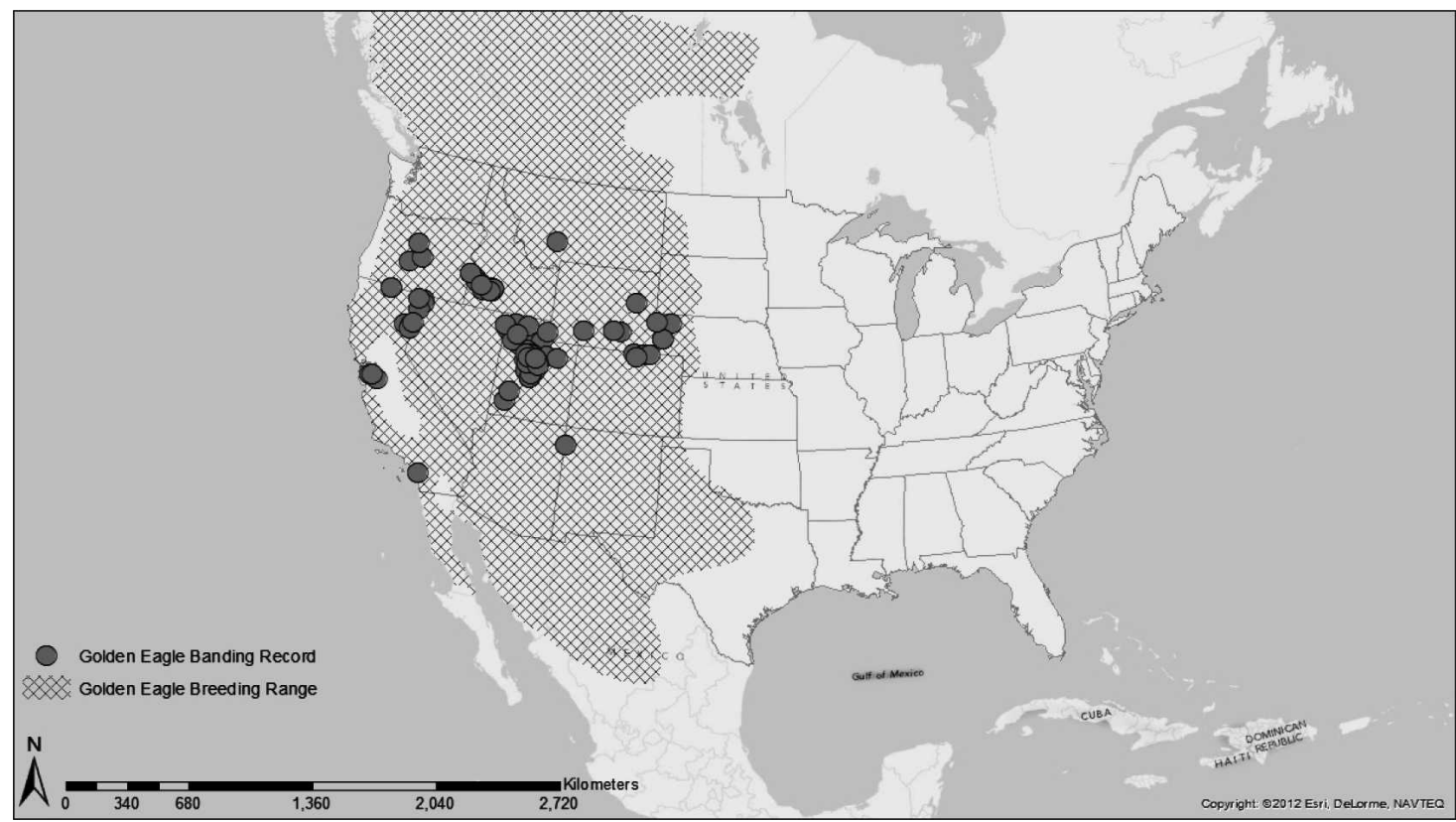

Figure 2. Breeding range (from Ridgely et al. 2007) and natal banding site of Golden Eagles subsequently encountered and included in natal dispersal analysis.

(Fig. 5). For the handful of cases where we know the actual distance between natal and first-breeding site, Bald Eagle natal dispersal distances for six male and one female Bald Eagle from the Greater Yellowstone Ecosystem ranged from 28 to $328 \mathrm{~km}$ with a median of $72 \mathrm{~km}$, and known natal dispersal distances for three male and one female Florida Bald Eagle ranged from 37 to $105 \mathrm{~km}$ with a median of $55 \mathrm{~km}$.

\section{DISCUSSION}

Banding data suggest Bald Eagles tended to disperse farther than Golden Eagles, with $80 \%$ of Golden Eagles dispersing $<110 \mathrm{~km}$ and $80 \%$ of Bald Eagles dispersing $<200 \mathrm{~km}$. Estimated natal dispersal distances from the banding sample were similar to confirmed natal dispersal distances for Bald Eagles in Florida and the Greater Yellowstone Ecosystem. Natal dispersal distances of Golden Eagles

Table 1. Maximum-likelihood fitting and Kolmogorov-Smirnov (KS) goodness-of-fit tests of empirical Bald and Golden eagle natal dispersal distance data derived from band reencounters with plausible theoretical distributions.

\begin{tabular}{|c|c|c|c|c|}
\hline SPECIES/GROUP & DISTRIBUTION & $\mathrm{AIC}$ & $\Delta \mathrm{AIC}$ & KS RESULT $\alpha=0.05$ \\
\hline Golden Eagle & lognormal & 1006.7 & 0.0 & Not rejected \\
\hline Golden Eagle & gamma & 1011.1 & 4.4 & Rejected \\
\hline Golden Eagle & normal & 1118.5 & 111.8 & Rejected \\
\hline Bald Eagle & lognormal & 10332.3 & 0.0 & Rejected \\
\hline Bald Eagle & gamma & 10412.3 & 80.0 & Rejected \\
\hline Bald Eagle & normal & 12002.6 & 1670.3 & Rejected \\
\hline Bald Eagle, female & lognormal & 922.0 & 0.0 & Not rejected \\
\hline Bald Eagle, female & gamma & 923.0 & 1.0 & Not rejected \\
\hline Bald Eagle, female & normal & 1015.8 & 93.8 & Rejected \\
\hline Bald Eagle, male & lognormal & 779.4 & 0.0 & Not rejected \\
\hline Bald Eagle, male & gamma & 781.3 & 1.9 & Not rejected \\
\hline Bald Eagle, male & normal & 920.4 & 141.0 & Rejected \\
\hline
\end{tabular}


Table 2. Estimated median, mean, and standard deviation (SD) natal dispersal distance (km) for Bald and Golden eagle data sets. Estimates were derived directly from samples (sample), using maximum likelihood methods assuming a lognormal distribution (maximum likelihood), and using a lognormal model in a Bayesian framework (posterior). See Methods for details.

\begin{tabular}{|c|c|c|c|}
\hline Species Group and Method & MEDIAN & ARITHMETIC MEAN & $\mathrm{SD}$ \\
\hline \multicolumn{4}{|l|}{ Golden Eagle } \\
\hline sample & 45.4 & 76.7 & 104.4 \\
\hline maximum likelihood & 48.5 & 73.9 & 83.6 \\
\hline posterior & 46.4 & $79.1^{\mathrm{a}}$ & 112.7 \\
\hline \multicolumn{4}{|l|}{ Bald Eagle } \\
\hline sample & 68.2 & 150.9 & 296.8 \\
\hline maximum likelihood & 69.5 & 151.8 & 281.2 \\
\hline posterior & 69.2 & $151.5^{\mathrm{b}}$ & 300.6 \\
\hline \multicolumn{4}{|l|}{ Bald Eagle, female } \\
\hline sample & 137.6 & 297.4 & 569.0 \\
\hline maximum likelihood & 138.7 & 293.7 & 531.8 \\
\hline posterior & 138.2 & $263.2^{\mathrm{c}}$ & 662.2 \\
\hline \multicolumn{4}{|l|}{ Bald Eagle, male } \\
\hline sample & 58.7 & 143.6 & 319.3 \\
\hline maximum likelihood & 59.6 & 139.3 & 307.9 \\
\hline posterior & 59.8 & $153.9^{\mathrm{d}}$ & 375.3 \\
\hline
\end{tabular}

a Highest-density interval (HDI) = 59.9-101.6.

b HDI $=136.3-169.2$.

c HDI $=198.3-449.7$.

${ }^{\mathrm{d}}$ HDI $=90.8-233.4$.

banded in southwestern Idaho $(n=6)$ ranged from $7 \mathrm{~km}$ to $130 \mathrm{~km}$ (Steenhof et al. 1984) and were comparable to those presented here. In Spain, species of Aquila had highly variable natal dispersal distances. Urios et al. (2007) recorded a natal dispersal distance of $26 \mathrm{~km}$ for a Golden Eagle. A female Bonelli's Eagle (A. fasciatus) bred $441 \mathrm{~km}$ from its natal nest (Cadahía et al. 2010), and the range of natal dispersal distances for 12 Spanish Imperial Eagles (A. adalberti) was between 3 and $312 \mathrm{~km}$ (González et al. 2006). Thus, natal dispersal distances of Golden Eagles in the western U.S. appear similar to those of European Aquila, but this warrants further assessment and a more complete analysis.

Natal dispersal distance varied with sex for the Bald Eagle, with females dispersing $78 \mathrm{~km}$ farther than males on average. Female-biased natal dispersal is the typical pattern in birds (Greenwood and Harvey 1982) and has been documented for the closely related White-tailed Eagle (Haliaeetus albicilla; Whitfield et al. 2009). Such a pattern may exist for Golden Eagles as well, but there were too few Golden Eagles of known sex in our sample to test for a sex-effect on dispersal distance.
Although we found little evidence for a substantial difference in natal dispersal distances among eight regional Bald Eagle populations, banding data suggested a trend toward longer natal dispersal distances along a longitudinal gradient from east to west in the United States. Whitfield et al. (2009) found a negative relationship between nest density and natal dispersal in the White-tailed Eagle. The trend we observed for the Bald Eagle may also reflect relative nest (and suitable habitat) density, as natal dispersal distances were shorter in the generally higher-density Bald Eagle breeding populations in the east compared to more sparsely distributed populations in the west, as is suggested by nest density data compiled for the post-delisting monitoring plan for the Bald Eagle (U.S. Fish and Wildlife Service 2009b). The comparatively high nesting density of Bald Eagles along the Pacific coast is an exception to this trend (U.S. Fish and Wildlife Service 2009b). However, our sample had few natal dispersal records from this part of the Pacific region; thus, our estimates for this region pertain more to natal dispersal distances east of the Cascades and in California. 

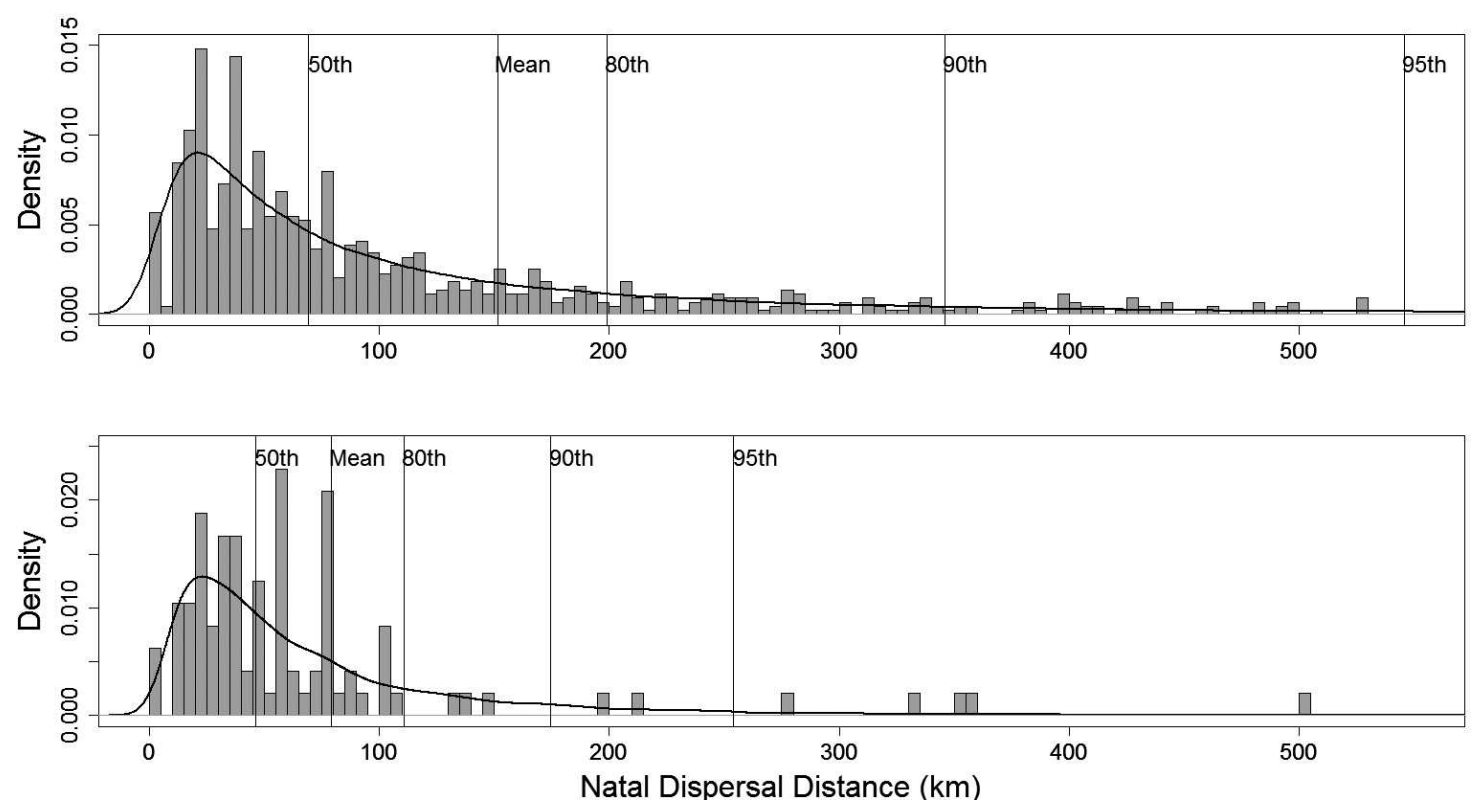

Figure 3. Empirical (histogram) and theoretical lognormal (smoothed line) natal dispersal distance distributions for Bald (top, $n=878$ ) and Golden (bottom, $n=96$ ) eagles. The theoretical lognormal distribution for the Bald Eagle has parameters $\mu=4.24, \sigma=1.25$, and the theoretical lognormal distribution for the Golden Eagle has parameters $\mu=3.88$, $\sigma=0.92$. Distributions are truncated at $550 \mathrm{~km}$; actual distribution for Bald Eagles extends to $1000 \mathrm{~km}$, but at very low densities.
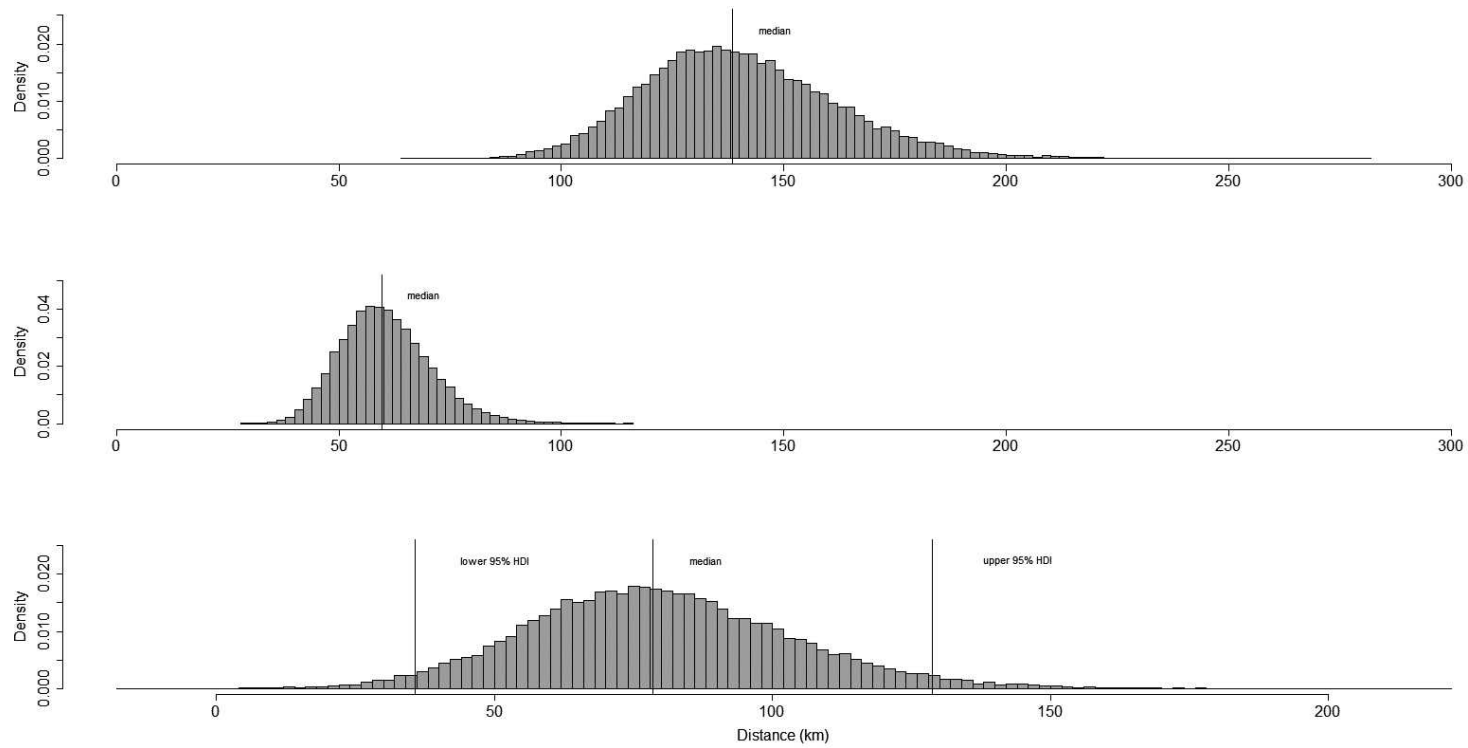

Figure 4. Posterior median distributions for female (top) and male (middle) Bald Eagle natal dispersal distances and the difference between the posterior median distributions (bottom). Note that a difference of zero is outside the range of credible values. 


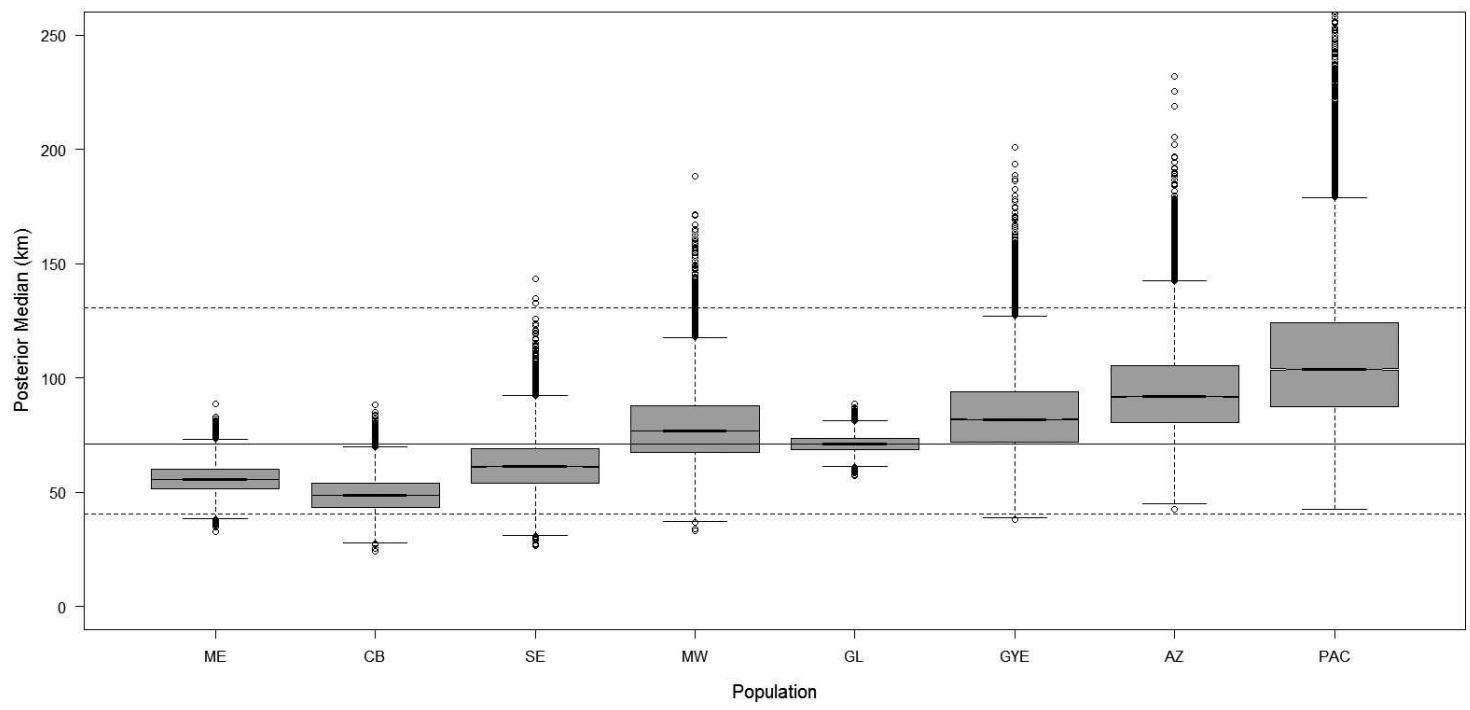

Figure 5. Box plots of posterior median natal dispersal distances for regional Bald Eagle populations. Shaded boxes represent median $50 \%$ interquantiles, whiskers represent minimum and maximum values, and values beyond are outliers. Horizontal lines within shaded boxes are medians for each population; solid horizontal line across full graph is grand median and dashed lines are the upper and lower highest density intervals for the grand median. Geographic regions are $\mathrm{ME}=$ Maine, $\mathrm{CB}=$ Chesapeake Bay, $\mathrm{SE}=$ Southeast, $\mathrm{MW}=$ Midwest, GL $=$ Great Lakes, GYE $=$ Greater Yellowstone Ecosystem, $\mathrm{AZ}=$ Arizona, and PAC = Pacific; see text for more details.

U.S. Fish and Wildlife Service (2009a) used natal dispersal distances for each species to define a range of effect for management decisions affecting eagles. Contrary to U.S. Fish and Wildlife Service (2009a), we found natal dispersal distances of Bald Eagles were generally greater than those of Golden Eagles. Our analyses produced estimated median and mean natal dispersal distances greater than those calculated by U.S. Fish and Wildlife Service (2009a) for the Bald Eagle, and lower than the U.S. Fish and Wildlife Service's recommendation for the Golden Eagle. Our analysis differed from that conducted by the U.S. Fish and Wildlife Service (2009a) in that we included more records overall, we excluded a few records that likely did not represent natal dispersal, and we took into account the lognormal distribution of the data. We believe our report is an important update of the U.S. Fish and Wildlife Service's (2009a) analysis.

Depending on the management policy and circumstances, choice of a natal dispersal value in the range of the $50^{\text {th }}$ to $90^{\text {th }}$ quantile of the distribution as an effect-distance for breeding populations of both species of eagle seems reasonable. For Golden Eagles, this range is $46-175 \mathrm{~km}$, and for Bald Eagles, 69-346 km. This range includes the natal dispersal value of $69 \mathrm{~km}$ currently in use for Bald Eagles, but the $90^{\text {th }}$ quantile for Golden Eagles is slightly less than the $225 \mathrm{~km}$ currently in use for this species (U.S. Fish and Wildlife Service 2012). Managers should consider potential sexual differences in natal dispersal distance when making management decisions, and potential consequences of that difference on sex ratios. Finally, Whitfield et al. (2009) and our analysis for Bald Eagles suggest there may be an inverse relationship between natal dispersal distance and nesting density for Haliaeetus eagles. The majority of Golden Eagle banding records in our sample are from eagles banded within the core portion of the species' range in the coterminous U.S. Thus, our findings may not be representative of Golden Eagles in areas of sparse distribution or near the range periphery. In such situations, natal dispersal distances would likely be farther.

\section{ACKNOWLEDGMENTS}

We thank the many licensed bird banders whose records are included here; without their dedicated efforts, analyses such as this would not be possible. We are especially indebted to K. Keller, whose extensive and long-term banding of Utah Golden Eagle nestlings resulted in the largest proportion of encounters for that species in this analysis. 
Navajo Nation Department of Justice provided financial resources and M. Harmata extended exceptional tolerance of the junior authors and logistical support of this effort. Additional support was provided by the U.S. Fish and Wildlife Service's Office of the Science Advisor and the Division of Migratory Bird Management. We thank M. Otto for statistical advice. P. Whitfield, C. McIntyre, and two anonymous reviewers provided constructive comments on drafts of our paper. The findings and conclusions in this article are those of the authors and do not necessarily represent the views of the U.S. Fish and Wildlife Service.

\section{Literature Cited}

Baker, M., N. Nur, ANd G.R. Geupel. 1995. Correcting biased estimates of dispersal and survival due to limited study area: theory and an application using wrentits. Condor 97:663-674.

BloOm, P.H. AND W.S. Clark. 2001. Molt and sequences of plumages of Golden Eagles and a technique for inhand ageing. North American Bird Bander 26:97-113.

Brown, L.H. And D. Amadon. 1968. Eagles, hawks and falcons of the world. County Life Books, London, U.K.

BueHLER, D.A. 2000. Bald Eagle (Haliaeetus leucocephalus). In A. Poole and F. Gill [EDS.], The birds of North America online, No. 506. Cornell Lab of Ornithology, Ithaca, NY U.S.A. http://bna.birds.cornell.edu/bna/ species/506 (last accessed 1 May 2012).

Cadahía, L., P. López-López, V. URios, and J.J. Negro. 2010. Satellite telemetry reveals individual variation in juvenile Bonelli's Eagle dispersal areas. European Journal of Wildlife Research 56:923-930.

DALY, L.E. 2000. Interpretation and uses of medical statistics, Fifth Ed. Blackwell Science, Malden, MA U.S.A.

Delignette-Muller, M.L., M.L. Delignette, R. Pouillot, J.-B. Denis, And C. Dutang. 2012. Package "fitdistrplus." http://mirror.hmdc.harvard.edu/CRAN/web/ packages/fitdistrplus/fitdistrplus.pdf (last accessed 25 November 2012).

FurRer, R., D. NyChKa, S. SAIN, ANd M.D. NychKa. 2009. Package "fields." R Foundation for Statistical Computing, Vienna, Austria. http://www.idg.pl/mirrors/ CRAN/web/packages/fields/fields.pdf (last accessed 22 December 2012).

Gelman, A. AND J. Hill. 2007. Data analysis using regression and multilevel/hierarchical models. Cambridge University Press, Cambridge, U.K.

González, L.M., J. Oria, A. Margalida, R. Sánchez, L. Prada, J. Caldera, A. Aranda, and J.I. Molina. 2006. Effective natal dispersal and age of maturity in the threatened Spanish Imperial Eagle. Bird Study 53: 285-293.

Greenwood, P. And P.H. Harvey. 1982. The natal and breeding dispersal of birds. Annual Review of Ecology, Evolution, and Systematics 13:1-21.

Harmata, A.R., G.J. Montopoli, B. OAKleaf, P.J. Harmata, AND M. Restani. 1999. Movements and survival of Bald Eagles banded in the Greater Yellowstone Ecosystem. Journal of Wildlife Management 63:781-793.
HunT, W.G. 1998. Raptor floaters at Moffat's equilibrium. Oikos 82:191-197.

JoLIE, M. 1947. Plumage changes in the Golden Eagle. Auk 64:549-576.

KERY, M. 2010. Introduction to WinBUGS for ecologists: Bayesian approach to regression, ANOVA, mixed models and related analyses. Elsevier, Boston, MA U.S.A.

Kochert, M.N., K. Steenhof, C.L. MCIntyre, And E.H. Craig. 2002. Golden Eagle (Aquila chrysaetos). In A. Poole and F. Gill [EDs.], The birds of North America online, No. 684. Cornell Lab of Ornithology, Ithaca, NY U.S.A. http://bna.birds.cornell.edu/bna/species/ 684 (last accessed 29 April 2012).

Koenig, W.D., D. Van Vuren, And P.N. Hooge. 1996. Detectibility, philopatry, and the distribution of dispersal distances in vertebrates. Trends in Ecology and Evolution 11:514-517.

KRUSCHKE, J.K. 2011. Doing Bayesian data analysis: a tutorial with R and BUGS. Academic Press, Burlington, MA U.S.A.

Lunn, D.J., A. Thomas, N. Best, and D. Spiegelhalter. 2000. WinBUGS-a Bayesian modelling framework: concepts, structure, and extensibility. Statistics and Computing 10:325-337.

Millsap, B.A., T. Breen, E. McConnell, T. Steffer, L. Phillips, N.J. Douglass, and S. TAYlor. 2004. Comparative fecundity and survival of Bald Eagles fledged from suburban and rural natal areas in Florida. Journal of Wildlife Management 64:1018-1031.

Penteriani, V. And M.M. Delgado. 2009. Thoughts on natal dispersal. Journal of Raptor Research 43:90-98.

, M. FerRer, AND M.M. Delgado. 2011. Floater strategies and dynamics in birds, and their importance in conservation biology: towards an understanding of nonbreeders in avian populations. Animal Conservation 14:233-241.

R Development Core Team. 2008. R: A language and environment for statistical computing. 2.15.0 edition. $\mathrm{R}$ Foundation for Statistical Computing, Vienna, Austria. http://www.R-project.org (last accessed 17 October 2013).

Ridgely, R.S., T.F. Allnut, T. Brooks, D.K. McNicol, D.W. Mehlman, and J.R. Zook. 2007. Digital distribution maps of the birds of the western hemisphere, version 3.0. NatureServe, Arlington, VA U.S.A. http:// www.natureserve.org/getData/birdMaps.jsp (last accessed 17 October 2013).

Steenhof, K., M.N. Kochert, And J.H. Doremus. 1983. Nesting of subadult Golden Eagles in southwestern Idaho. Auk 100:743-747.

— — - AND M.Q. MoRITSCH. 1984. Dispersal and migration of southwestern Idaho raptors. Journal of Field Ornithology 55:357-368.

U.S. Fish AND Wildlife Service. 2009a. Final environmental assessment: proposal to permit take as provided under the Bald and Golden Eagle Protection Act. U.S. Fish and Wildlife Service, Washington, DC U.S.A. 
http://www.fws.gov/migratorybirds/CurrentBirdIssues/ Management/BaldEagle/FEA_EagleTakePermit_Final. pdf (last accessed 17 October 2013).

2009b. Post-delisting monitoring plan for the Bald Eagle (Haliaeetus leucocephalus) in the contiguous United States. Divisions of Endangered Species and Migratory Birds and State Programs, Midwest Regional Office, Twin Cities, Minnesota. http://ecos.fws.gov/ docs/species/doc3240.pdf (last accessed 17 October 2013).

2012. Eagle conservation plan guidance. Module 1 - land-based wind energy. Version 2. Division of Migratory Bird Management. http://www.fws.gov/ migratorybirds/PDFs/Eagle\%20Conservation \% 20Plan \%20Guidance-Module\%201.pdf (last accessed 17 October 2013).
Urios, V., A. Soutullo, P. López-López, L. Cadahía, R. Liminana, AND M. Ferrer. 2007. The first case of successful breeding of a Golden Eagle (Aquila chrysaetos) tracked from birth by satellite telemetry. Acta Ornithologica 42:205-209.

WhEELER, B.K. AND W.S. CLARK. 1995. A photographic guide to North American raptors. Academic Press, Harcourt and Brace Publishing Company, New York, NY U.S.A.

Whitfield, D.P., A. Douse, R.J. Evans, J. Grant, J. Love, D.R.A. MCLeOD, R. ReID, AND J.D. Wilson. 2009. Natal and breeding dispersal in a reintroduced population of White-tailed Eagles Haliaeetus albicilla. Bird Study 56:177-186.

Received 14 January 2013; accepted 26 August 2013 Associate Editor: Vincenzo Penteriani 


\section{ERRATA}

Diurnal Raptors in Los Tuxtlas Biosphere Reserve, Mexico: Current Presence and Relative Abundance. Miguel Angel De Labra, Patricia Escalante, and Tiberio Monterrubio-Rico.

Due to an editorial error, one species was inadvertently named incorrectly in this article that was published in Journal of Raptor Research 47(4):392-399. The species termed Gray-lined Hawk (Buteo nitidus) in the article should have been called Gray Hawk (Buteo plagiatus).
Natal Dispersal Distance of Bald and Golden Eagles Originating in the Coterminous United States as InfERred from BAND ENCOUNTERs. Brian A. Millsap, Alan R. Harmata, Dale W. Stahlecker, and David G. Mikesic.

Due to an editorial error, one sentence of the abstract was misprinted for this article that was published in Journal of Raptor Research 48(1):13-23. The sentence should have been as follows:

Median natal dispersal distance for female Bald Eagles was $78.3(\mathrm{HDI}=35.4-128.6) \mathrm{km}$ greater than for males; we lacked sufficient data to analyze natal dispersal distance by sex for Golden Eagles. 